\title{
Trace elements in otoliths indicate the use of open-coast versus bay nursery habitats by juvenile California halibut
}

\author{
Graham E. Forrester ${ }^{1, *}$, Stephen E. Swearer ${ }^{2, * *}$ \\ ${ }^{1}$ Department of Biological Sciences, University of Rhode Island, Kingston, Rhode Island 02881, USA \\ ${ }^{2}$ Department of Ecology, Evolution, and Marine Biology, University of California, Santa Barbara, California 93106, USA
}

\begin{abstract}
Many coastal fishes use inshore nursery habitats as juveniles, but it is often difficult to define which nursery areas supply most recruits to adult populations. We tested whether trace element concentrations in otoliths can be used to identify which of 2 nursery habitats (bays or shallow open coast) were occupied by juvenile California halibut. Juveniles from bays in 1998 had concentrations of $\mathrm{Cu}$ and $\mathrm{Pb}$ in their otoliths that were higher than those in open coast juveniles of the same year. This broad-scale difference between bay and open coast juveniles remained intact when bay juveniles from 1994 to 1997 were added to the comparison, and juvenile halibut could be assigned to their nursery habitat of origin quite accurately $(83 \%)$ using otolith concentrations of $\mathrm{Cu}$ and $\mathrm{Pb}$. At a finer spatial scale, otolith concentrations of $\mathrm{Cu}$ and $\mathrm{Pb}$ differed among individual bays, and fish from the same bay could differ among years, precluding their use as markers of nursery habitat use at these scales. Like halibut otoliths, sediments from bays had higher concentrations of $\mathrm{Cu}$ and $\mathrm{Pb}$ than open coast nursery sites, and this difference was consistent over $11 \mathrm{yr}$. Otoliths and sediments from individual bays, however, showed no correlation in $\mathrm{Cu}$ and $\mathrm{Pb}$ concentrations. The concentration of $\mathrm{Cu}$ and $\mathrm{Pb}$ in sediments and their deposition in otoliths were thus loosely matched at a broad scale, though the underlying cause of this link is not known. A discriminant model, parameterized using $\mathrm{Cu}$ and $\mathrm{Pb}$ levels in juvenile otoliths, was used to classify prior nursery habitat use by 19 larger halibut (of unknown origin). Eleven of these halibut had high levels of $\mathrm{Cu}$ and $\mathrm{Pb}$ in the part of the otolith deposited as a juvenile, and were classified as of bay origin. The other 8 halibut had low otolith $\mathrm{Cu}$ and $\mathrm{Pb}$ levels in the juvenile portion of their otoliths and were classified as having used open coast nurseries. Overall, our results suggest that this approach has the potential to allow identification of nursery habitat use by California halibut at a broad scale (bay vs open coast) but not at a fine scale (individual bays).
\end{abstract}

KEY WORDS: Estuaries $\cdot$ Nursery habitat $\cdot$ Otoliths $\cdot$ Trace elements $\cdot$ Halibut

\section{INTRODUCTION}

\section{Background}

Most coastal fish have populations that occupy spatially distinct habitats at different stages in their life history. Many species, for example, use protected

\footnotetext{
*E-mail: gforrester@uri.edu

** Present address: Department of Zoology, University of Melbourne, Victoria 3010, Australia
}

inshore habitats such as estuaries, bays and salt marshes as juvenile nursery grounds, but migrate offshore to deeper habitats as adults (Able \& Fahay 1998). Many fish using inshore nurseries are the subject of commercially important fisheries (Houde \& Rutherford 1993). The ability to quantify the degree to which fishes are exchanged among habitats is critical to understanding the ecology of these populations and to successfully manage their harvesting. For species using bays as nurseries, approaches used to assess the 
importance of the nursery habitat have often been qualitative, and quantitative approaches have usually been indirect. Some authors have assessed importance as the proportion of the life history (Cyrus \& Martin 1991) or amount of time spent in a nursery (Szedlmayer \& Able 1993). Many authors have determined the importance of nursery habitats based on the abundance of juvenile fishes in a specific nursery (Reichert \& van der Veer 1991) or by comparing abundances among several nursery areas (Kerstan 1991). A limitation of these measures is that they do not identify natal origin or allow estimates of how many juveniles successfully recruit to the adult population from different nurseries.

A new approach that has the potential to provide more direct measures of the exchange of individuals among sites employs the analysis of trace elements in otoliths, balance organs found in the ear canals of all teleost fishes. Otoliths grow continually by the deposition of calcium carbonate crystals within a protein matrix. As the otolith material accretes, it incorporates trace elements from the environment that have been absorbed across the gills or gut and entered the fishes' bloodstream (Campana 1999). Fish collected from different locations often vary in the concentrations of various trace elements in their otoliths. Examples include comparisons of fish occupying different inshore sites (Gillanders \& Kingsford 1996, 2000, Milton et al. 1997, Thorrold et al. 1997, 1998a,b, 2001), different areas on a continental shelf (Campana \& Gagne 1994, Campana et al. 1994, 1995, 1999), different deep-water oceanic sites (Edmunds et al. 1991), and different coral reefs (Patterson et al. 1999, Swearer et al. 1999).

The causes of these site-specific differences in otolith chemistry are still poorly understood (Campana 1999). Some trace elements are deposited in otoliths in rough correspondence to their bulk concentration in the water column (Mugiya et al. 1991, Geffen et al. 1998, Bath et al. 2000, Milton \& Chenery 2001), and water temperature and salinity also influence how some elements are incorporated into otoliths (Fowler et al. 1995a,b, Bath et al. 2000). Although not empirically documented, it is also possible that other environmental variables, including the uptake and incorporation of elements from the tissues of ingested prey, may influence variation in otolith elemental composition. Spatial gradients in any of these environmental conditions might produce reliable markers of site occupancy (elemental 'tags') if variation in otolith chemistry can be matched to specific environmental conditions. Sitespecific differences in otolith chemistry might also occur, even in the absence of environmental gradients, if there are genetic differences among populations in the physiological regulation of elemental deposition (Campana \& Gagne 1994).
Whatever their underlying cause, there is still a pressing need to test the consistency of observed sitespecific differences in otolith chemistry. Most studies to date have compared relatively few sites, and have compared fish collected in only 1 year. Our primary aim in this study was to test for elemental tags indicating nursery habitat use at 2 spatial scales, and to assess whether patterns of trace-element deposition were consistent among years. We tested for large-scale elemental tags by comparing juvenile fishes from the 2 general nursery habitats occupied by our study species: bays and shallow open coast sites. We tested for small-scale elemental tags by comparing juveniles from individual bays. At both large and small spatial scales, we tested for temporal consistency in elemental tags by comparing juvenile fish collected over several years.

We also assessed whether variation in the concentration of trace elements in sediments varied in space and time in a way that matched the otolith chemistry of juvenile fishes resident in those locations. The lack of an association would allow us to exclude sediment trace elements as a cause of elemental deposition. A positive correlation, while not indicating causation, would suggest that a gradient in trace element concentrations across habitats caused any elemental tag in the otoliths. Lastly, we test whether it might be possible to identify the nursery habitat used previously by adults. To do this, we analysed otoliths from a small sample of larger fishes that had migrated to the adult habitat offshore and whose prior nursery habitat was unknown. Chemical analyses targeted both the central part of the otolith, deposited during residence in the nursery habitat, and the outer portion that was deposited after the fish had migrated to adult habitat. To test for natural tags indicating past nursery habitat use, the chemical composition of their otolith centre was compared to the composition of juvenile otoliths of known origin.

\section{The study system}

Our study species, the California halibut Paralichthys californicus, is the subject of a valuable fishery in California (Frey 1971) and has a life history typical of many coastal species. Adults occur on the continental shelf adjoining the West Coast of the United States and northern Baja California Sur, Mexico, but are concentrated primarily in the Southern California Bight (Frey 1971). Juvenile halibut (9 to $10 \mathrm{~mm}$ standard length [SL]) settle in shallow coastal habitats after a 20 to $30 \mathrm{~d}$ pelagic larval phase (Moser \& Watson 1990). Juveniles then migrate into 2 distinct nursery habitats: (1) protected semi-enclosed bays and estuaries (which we will refer to as 'bays' for convenience), and (2) shal- 
low $(<30 \mathrm{~m})$ inshore areas on the open coast (Kramer 1991). In both habitats, they are found in unvegetated areas on sandy sediments (Allen \& Herbinson 1990, Valle et al. 1999). Juveniles on the open coast are at extremely low densities compared to those in bays, but since this habitat makes up virtually the entire coastline, the absolute number of juveniles occupying open coast habitat may be high (Kramer 1990). After about $1 \mathrm{yr}$, juveniles (140 to $220 \mathrm{~mm} \mathrm{SL}$ ) from both nursery habitats move offshore to join adult populations in deeper open coast areas. Surveys of the distribution and abundance of age- 0 halibut can be used to estimate the total abundance of juveniles in different habitats and, by extrapolation, what fraction of the adult population originates from each (Allen et al. 1990). These extrapolations are difficult, however, because the scarcity of open coast juveniles makes it difficult to accurately estimate their abundance.

Chemical tags recorded in otoliths might provide a more direct estimate of prior residence in specific nurseries if the central portion of adult otoliths, deposited during the first year of life, retained a chemical tag indicating juvenile habitat. The importance of bay nurseries could then be measured as the fraction of successful recruits to the adult population that originated from bays. There are several trace elements that are potential markers for differentiating bay from open coast sites (Al, Mn, Co, Ni, Cu, Zn, Sr, Ag, Cd, Sn, Ba, and $\mathrm{Pb}$ ). Most promising are elements ( $\mathrm{Al}, \mathrm{Ni}, \mathrm{Cu}, \mathrm{Zn}$, $\mathrm{Ag}, \mathrm{Cd}, \mathrm{Pb}$ ) whose concentrations in the water column and sediments are generally higher in bays than at inshore open coast sites in southern and central California (Johnson et al. 1988, Flegal \& Sañudo-Wilhelmy 1993, van Geen \& Luoma 1993, Sañudo-Wilhelmy \& Flegal 1996, Zirino et al. 1998). In the deeper offshore coastal areas occupied by adult halibut, trace element concentrations are similar to, or slightly lower than, concentrations inshore on the open coast (SañudoWilhelmy \& Flegal 1996).

\section{MATERIALS AND METHODS}

Differences in otolith chemistry of juvenile halibut occupying bay and open coast nurseries. We first collected juvenile California halibut residing in bay and open coast nursery areas to test for differences in the trace element chemistry of their otoliths. Juvenile halibut from bays were collected using beach seines, and juveniles from the open coast were collected using trawls towed behind small boats. Open coast nursery sites are difficult to sample and contain very low densities of juvenile halibut. As a result, many collecting trips yielded no halibut, and we successfully sampled open coast sites only in 1998. In this year, we collected

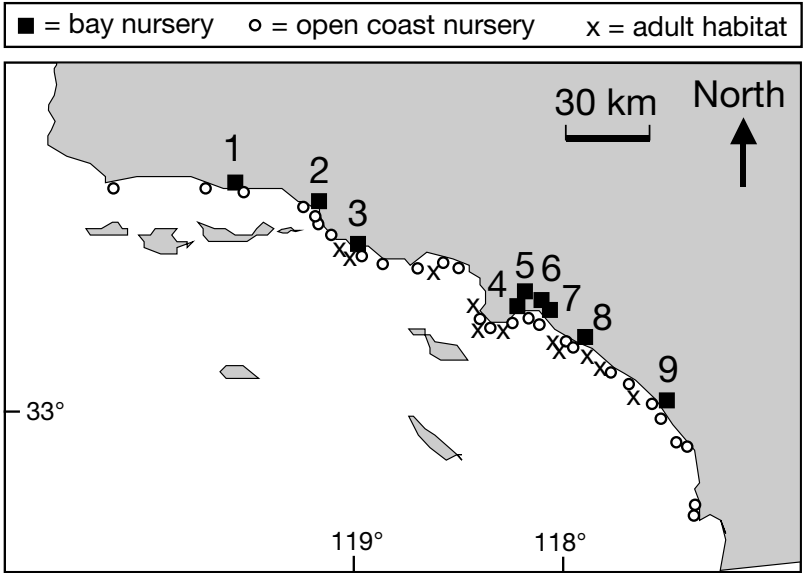

Fig. 1. Map of southern California showing bay and shallow open coast nursery sites sampled for juvenile California halibut, and deeper adult habitat sampled for larger fish. Bay sites are numbered as follows: 1 = Carpinteria Marsh, $2=$ Ventura Harbor, 3 = Mugu Lagoon, 4 = Los Alamitos Bay, $5=$ Los Angeles Harbor, $6=$ Long Beach Harbor, $7=$ Anaheim Bay, $8=$ Newport Bay, $9=$ Batiquitos Lagoon

69 juveniles from 27 inshore locations (depth $<28 \mathrm{~m}$ ) from San Diego to Pt. Conception (Fig. 1). In 1998, we also collected 65 juveniles from 7 bays in southern California spread along the same region of coastline (Fig. 1). The bays sampled were a reasonable cross section of those in the region in terms of size, fish habitat, and human impact (Mearns et al. 1991, Ferren et al. 1996). Comparison of the 1998 juveniles thus allowed us to test for an overall difference between bay and open coast halibut using fish collected in the same year. We collected 152 additional juveniles in bays from 1994 to 1997 . Most of these juveniles were collected from the 7 original bays, but 2 additional bays were also sampled (Fig. 1, Table 1). We used these samples to assess the reliability of the bay natural tag. To do this, we tested whether any differences between bay and open coast juveniles that were detected in 1998 remained intact when bay juveniles from other years and sites were added. We also made more selective comparisons to test for spatial and temporal variation in the otolith chemistry of juveniles from specific bays. We tested for differences among years in a single bay, as well as differences among bays in a given year.

All juvenile halibut were frozen before preparation for chemical analyses to avoid effects of varied storage procedures on trace-element analysis (Milton \& Chenery 1998). The juvenile halibut collected ranged in size from 33 to $206 \mathrm{~mm} \mathrm{SL}$ (mean = $103 \mathrm{~mm}$ ) and so had spent most of their lives in the nursery habitat from which they were collected (Kramer 1991). We therefore analysed entire otoliths (1 sagitta per fish) to get an integrated measure of their chemistry. Concentra- 
Table 1. Paralichthys californicus. Mean concentrations ( $\mu \mathrm{g} \mathrm{g}^{-1} \mathrm{Ca}$ ) of $\mathrm{Cu}$ and $\mathrm{Pb}$ in the otoliths of juvenile halibut. The location of each bay is indicated in Fig. 1

\begin{tabular}{|c|c|c|c|c|c|c|}
\hline \multirow[t]{2}{*}{ Bay } & \multirow[t]{2}{*}{$\mathrm{n}$} & \multirow{2}{*}{$\begin{array}{c}\text { Year } \\
\text { sampled }\end{array}$} & \multicolumn{2}{|c|}{$\mathrm{Cu}$} & \multicolumn{2}{|c|}{$\mathrm{Pb}$} \\
\hline & & & Mean & SE & Mean & SE \\
\hline Carpinteria Marsh & 19 & 1994 & 1.554 & 0.062 & 0.030 & 0.004 \\
\hline Carpinteria Marsh & 9 & 1995 & 5.141 & 0.977 & 0.065 & 0.011 \\
\hline Carpinteria Marsh & 19 & 1996 & 4.832 & 0.861 & 0.061 & 0.021 \\
\hline Ventura Harbor & 2 & 1998 & 0.749 & 0.531 & 0.282 & 0 \\
\hline Mugu Lagoon & 7 & 1997 & 0.342 & 0.09 & 0.15 & 0.035 \\
\hline Mugu Lagoon & 7 & 1998 & 0.414 & 0.103 & 0.172 & 0.073 \\
\hline Los Alamitos Bay & 21 & 1994 & 1.670 & 0.09 & 0.014 & 0.002 \\
\hline Los Alamitos Bay & 22 & 1996 & 0.898 & 0.158 & 0.106 & 0.027 \\
\hline Los Alamitos Bay & 5 & 1998 & 0.050 & 0.034 & 0.030 & 0.021 \\
\hline Los Angeles Harbor & 10 & 1996 & 0.336 & 0.04 & 0.021 & 0.002 \\
\hline Long Beach Harbor & 8 & 1998 & 0.159 & 0.015 & 0.004 & 0.004 \\
\hline Anaheim Bay & 20 & 1994 & 1.530 & 0.044 & 0.039 & 0.011 \\
\hline Anaheim Bay & 25 & 1996 & 2.731 & 0.229 & 0.028 & 0.003 \\
\hline Anaheim Bay & 3 & 1998 & 0.552 & 0.396 & 0.087 & 0.079 \\
\hline Newport Bay & 7 & 1998 & 1.245 & 0.091 & 0.863 & 0.595 \\
\hline Batiquitos Lagoon & 33 & 1998 & 0.754 & 0.166 & 0.057 & 0.018 \\
\hline
\end{tabular}

tions of trace elements in otoliths were determined using inductively coupled plasma mass spectrometry (ICP-MS). The otoliths collected from both nursery habitats in 1998, and 103 additional otoliths collected from bays in earlier years, were analysed using a Finnegan MAT high-resolution ICP-MS. A further 113 otoliths, all collected in bays prior to 1997, were analysed using a different ICP-MS instrument (a VG Elemental PlasmaQuad 2+) because the Finnegan MAT was unavailable when these otoliths were analysed.

Otoliths analysed using the PlasmaQuad 2+ ICP-MS were first dissected and weighed to the nearest $10 \mu \mathrm{g}$. They were then crushed between 2 borosilicate plates and transferred to a $1.5 \mathrm{ml}$ microcentrifuge vial. Each sample was then soaked in $500 \mu \mathrm{l}$ of $5 \% \mathrm{NaOCl}$ for a total of $72 \mathrm{~h}$ to remove organic contaminants. The $\mathrm{NaOCl}$ solution was changed 6 times (every $12 \mathrm{~h}$ ) during the soaking process. The otoliths were then rinsed 3 times with de-ionized water (18 MOhm) and heat-rinsed for $1 \mathrm{~h}$ to remove any remaining bleach. After 3 more rinses with de-ionized water, the otoliths were transferred to acid-leached polypropylene $1.5 \mathrm{ml}$ microcentrifuge vials. The otoliths were next acid-leached 3 times with $0.001 \mathrm{~N} \mathrm{HNO}_{3}$ (Fisher Optima grade) to remove adsorbed elements, and allowed to air-dry in a laminar flow bench. Each sample was then dissolved in $0.14 \mathrm{~N}$ $\mathrm{HNO}_{3}$ (Fisher Optima grade). The volume of acid used was varied, depending on the otolith weight, to yield a solution with a calcium concentration of approximately $0.06 \mathrm{M}$. Next, $25 \mu \mathrm{l}$ of this primary sample solution was transferred to another acid-leached polypropylene $1.5 \mathrm{ml}$ microcentrifuge vial. It was then diluted to a final volume of $1.5 \mathrm{ml}$ with $1 \% \mathrm{HNO}_{3}$ (Fisher Optima grade) containing $\mathrm{Sc}_{\mathrm{c}} \mathrm{Y}$, and In as internal standards. These dilutions yielded a final sample calcium concentration of approximately $1 \mathrm{mM}$ and were chosen to minimize the magnitude and betweensample variability of matrix effects.

Samples were introduced to the PlasmaQuad 2+ ICP-MS with a Cetac U5000 AT ultrasonic nebulizer modified to handle low sample flow rates. Samples were run in blocks of 13, with samples from each site and collection date placed randomly in each block, in order to avoid possible bias due to sequence effects. Also included in each block were 2 samples of a consistency standard (a matrix-matched solution containing all elements analyzed in concentrations typically found in an otolith). The concentrations of elements in the sample were calculated using calibrations derived from 3 external standards that were run before and after each block of samples. Standards were matrix-matched and optimized for each element to yield a range of concentrations that would bracket the range of expected sample concentrations.

The Finnegan MAT high-resolution ICP-MS was coupled with either a Cetac MCN-100 microconcentric nebulizer (pumped at $60 \mu \mathrm{min}^{-1}$ ) or a glass expansion

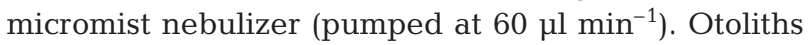
analysed using this instrument were prepared as just described, except that these otoliths were not crushed because paired tests revealed no differences in the chemistry of crushed and uncrushed otoliths. Other slight differences included the use of polyethylene rather than polypropylene vials and final dilution of the sample to a slightly different Ca concentration (5 to $7.5 \mathrm{mM})$. Trace element concentrations were also determined using a similar procedure to that described for the first 113 otoliths. Samples were run in blocks of 18 , with samples from sites and collection date placed randomly in each block to avoid bias due to sequence effects. We also included matrix-matched external standards and a consistency standard in each block.

For both ICP-MS instruments, trace element concentrations were expressed relative to that of calcium 
( $\mu \mathrm{g}$ element $\mathrm{gCa}^{-1}$ ). Some of the elements screened were discarded because of analytical problems with 1 , or both, instruments ( $\mathrm{Al}, \mathrm{Ni}, \mathrm{Zn}, \mathrm{Sn}$ and $\mathrm{Ag}$ ) or because their concentrations were often below detection limits (Co and $\mathrm{Cd})$. For the remaining elements $(\mathrm{Mn}, \mathrm{Cu}, \mathrm{Sr}$, $\mathrm{Ba}, \mathrm{Pb}$ ), we tested whether the results from the 2 instruments were comparable. To do this, we dissected the right and left sagitta from 10 halibut and analysed 1 otolith using each instrument. The levels of most elements in the paired otoliths were highly correlated (correlation for $\mathrm{Mn}, \mathrm{r}=0.91, \mathrm{p}<0.001 ; \mathrm{Cu}, \mathrm{r}=0.97$, $\mathrm{p}<0.0001 ; \mathrm{Sr}, \mathrm{r}=0.93, \mathrm{p}<0.0005 ; \mathrm{Pb}, \mathrm{r}=0.75, \mathrm{p}=$ $0.013)$, so we pooled the data from the 2 methods for these elements. For Ba the correlation was weaker $(\mathrm{r}=0.65, \mathrm{p}=0.04)$ and measured concentrations were lower using the PlasmaQuad 2+ than the Element, so we analysed data from the 2 instruments separately. Detection limits (mean conc. of blank $+3 \times \mathrm{SD}$ ) for the instrument with the higher limits were as follows (all units ng $\mathrm{g}^{-1}$ ): $\mathrm{Mn}=0.038, \mathrm{Cu}=0.098, \mathrm{Sr}=6.192$, $\mathrm{Ba}=0.014, \mathrm{~Pb}=0.016$. Precision estimates (\% relative standard deviation) based on repeated analysis of the consistency sample were as follows: $\mathrm{Mn}=1.9 \%$, $\mathrm{Cu}=3.4 \%, \mathrm{Sr}=1.5 \%, \mathrm{Ba}=1.8 \%, \mathrm{~Pb}=2.3 \%$.

We performed analyses of variance (ANOVA) to test for differences in the mean concentrations of trace elements among nursery habitats. Separate univariate tests were performed for each element, rather than a combined multivariate ANOVA, because sample sizes differed among the elements. Prior to this, and all other analyses, assumptions of normality and homoscedasticity were checked (following Johnson \& Wichern 1998) and data always required $\log _{10}$-transformation in order to meet these assumptions. We then conducted discriminant analyses to test how accurately we could classify juvenile halibut to their nursery habitat using the concentrations of trace elements $(\mathrm{Mn}, \mathrm{Cu}, \mathrm{Sr}, \mathrm{Ba}$ and $\mathrm{Pb}$ ) in their otoliths. Because $\mathrm{Ba}$ data from the 2
ICP-MS instruments were not directly comparable, models that included this element were constructed separately for each instrument. Neither raw nor transformed data met the additional assumption of equal covariance matrices required for discriminant analysis, so we used a quadratic model that is robust to departures from this assumption (Johnson \& Wichern 1998). To evaluate the success of the discriminant model, we compared the numbers of samples actually taken from bays and open coast to a jackknifed estimate of the number predicted by the model to have been taken from each habitat (Lackenbruch \& Mickey 1968).

Differences in sediment trace-element chemistry among nursery habitats. The second part of our study was to define patterns of variability in trace-element chemistry within and among the 2 nursery habitats. A general trend for elevated levels of trace elements in bays is well-established, so our goals were (1) to test whether the specific trace elements identified as good natural tags in otoliths differed between bay and open coast nursery sites, (2) to test whether differences among nursery habitats were consistent among years, and (3) to test whether concentrations in otoliths and sediments were correlated at the scale of individual bays.

We used data on trace element concentrations in sediments from 5 monitoring studies in the study area (Table 2). Only data from suitable halibut nursery sites were used $(<30 \mathrm{~m}$ deep, close to seawater in salinity and over sandy/silty sediment). We compiled data on 3 elements measured in otoliths $(\mathrm{Mn}, \mathrm{Cu}$, and $\mathrm{Pb})$. The remaining 2 elements analysed in otoliths $(\mathrm{Sr}$ and $\mathrm{Ba}$ ) were not monitored in sediments. We used data from 1986 to 1998 , collected in most of the bays within the study area $(n=23)$ and from open coast sites spread from San Diego to Pt. Conception (for details see Fig. 2). Sampling and analytical methods differed slightly among the programs, but are broadly comparable (see

Table 2. Details of environmental monitoring data used to compare levels of trace elements in sediment samples from within bays and on the open coast

\begin{tabular}{|c|c|c|c|c|c|c|c|}
\hline \multirow[t]{2}{*}{ Agency } & \multirow[b]{2}{*}{$\mathrm{n}$} & \multirow[b]{2}{*}{ Dates } & \multirow{2}{*}{$\begin{array}{l}\text { - Bays } \\
\text { Area sampled }\end{array}$} & \multicolumn{3}{|c|}{${ }_{-}$Open coast $\longleftarrow$} & \multirow{2}{*}{$\begin{array}{l}\text { Reference for } \\
\text { methods }\end{array}$} \\
\hline & & & & $\mathrm{n}$ & Dates & Area sampled & \\
\hline $\begin{array}{l}\text { Bay Protection and Toxic } \\
\text { Cleanup Program* }\end{array}$ & 355 & 1992-1997 & $\begin{array}{l}21 \text { bays from Pt. Con- } \\
\text { ception to San Diego }\end{array}$ & 52 & $1992-1997$ & $\begin{array}{l}\text { Pt. Conception } \\
\text { to San Diego }\end{array}$ & $\begin{array}{l}\text { Stephenson } \\
\text { et al. (1994) }\end{array}$ \\
\hline $\begin{array}{l}\text { NOAA Status and } \\
\text { Trends Program* }\end{array}$ & 123 & $1986-1994$ & $\begin{array}{l}5 \text { bays from Marina } \\
\text { Del Rey to San Diego }\end{array}$ & 106 & $1986-1994$ & $\begin{array}{l}\text { Pt. Conception } \\
\text { to San Diego }\end{array}$ & $\begin{array}{l}\text { Lauenstein \& } \\
\text { Cantillo (1993) }\end{array}$ \\
\hline $\begin{array}{l}\text { Southern California Coastal } \\
\text { Water Research Project }\end{array}$ & 0 & - & - & 62 & 1994 & $\begin{array}{l}\text { Pt. Conception } \\
\text { to San Diego }\end{array}$ & $\begin{array}{l}\text { Schiff \& Gos- } \\
\text { sett (1998) }\end{array}$ \\
\hline $\begin{array}{l}\text { State Mussel Watch } \\
\text { Program }\end{array}$ & 18 & $1989-1993$ & $\begin{array}{l}6 \text { bays from Los Angeles } \\
\text { to San Diego }\end{array}$ & 5 & $1990-1991$ & San Diego & $\begin{array}{l}\text { Rasmussen } \\
\text { (1996) }\end{array}$ \\
\hline City of Los Angeles & 47 & $1993-1996$ & $\begin{array}{l}\text { Los Angeles/Long Beach } \\
\text { Harbor area }\end{array}$ & 75 & $1993-1996$ & $\begin{array}{l}\text { Pt. Dume to } \\
\text { Palos Verdes }\end{array}$ & $\begin{array}{l}\text { City of Los } \\
\text { Angeles (1997) }\end{array}$ \\
\hline
\end{tabular}




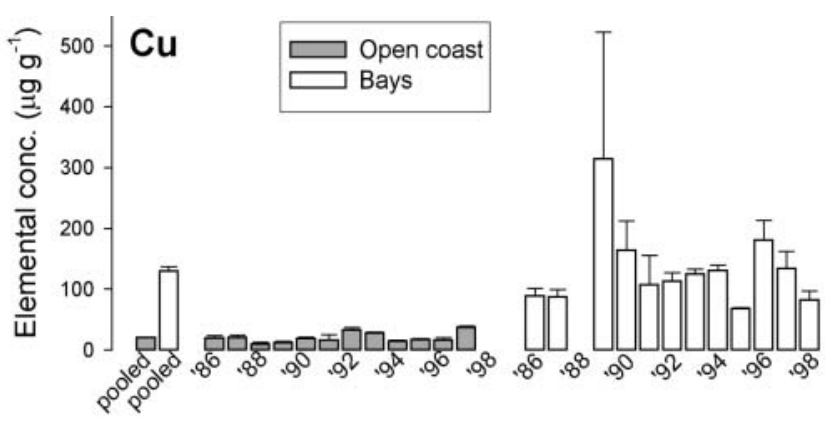

heim Bay (1994), Carpinteria Marsh (1994), Los Angeles Harbor (1996), Mugu Lagoon (1997 and 1998), and Ventura Harbor (1998). These data were used to test whether the mean concentration of each element in halibut otoliths was correlated with its mean concentration in the sediment at the scale of individual bays.

Assessing the potential to define past nursery habitat use in older halibut. The last part of our study was a preliminary test of whether chemical tags indicating past nursery habitat use could be identified in larger halibut that had moved offshore to the adult habitat. For this test, we collected 19 larger halibut in 1998 using trawls towed at 11 haphazardly selected sites in the study region (Fig. 1). All sites were offshore and in deeper water (21 to $60 \mathrm{~m}$ ) than those where juveniles were collected. The 19 halibut ranged in size from 240 to $345 \mathrm{~mm} \mathrm{SL}$ (mean $=273 \mathrm{~mm} \mathrm{SL}$ ) and so were 1 to 2 yr old when collected (Haaker 1975, Kramer 1990).

All halibut were kept frozen after collection and 1 otolith per fish (the left sagitta) was dissected and ground to a thin section on a microscope slide (following Kramer 1990). The otolith section was then mounted on a glass cover slip using cyanoacrylate adhesive, sonicated in deionized water (18 MOhm) and given a brief acid wash with $0.001 \mathrm{~N} \mathrm{HNO}_{3}$ (Fisher Optima grade). Trace elements were analysed at 5 locations spaced roughly evenly from the otolith core to the outer edge using laser ablation ICP-MS. We estimated the size (mm SL) of the halibut at the location of each laser sample by measuring the otolith radius at the crater left by the laser. The size estimate was based on a relationship between otolith radius $(x)$ and fish standard length $(y)$ obtained by pooling our data with those from 2 previous studies $(y=-7.93+67.2 x$ $+0.35 x^{2} ; n=169, r^{2}=0.95$ ) (Jensen 1990, Kramer 1990). Halibut migrate out of nursery habitats when they are between 140 and 200 mm SL (Kramer 1990), so we conservatively assumed that halibut were in a nursery habitat when $<140 \mathrm{~mm}$ SL and had moved offshore to adult habitat if $>140 \mathrm{~mm}$ SL (Kramer 1990). Using the otolith radius as a guide to fish size, we designated each trace element measurement as targeting part of the otolith deposited during residence in a nursery area (usually the 3 inner measurements) or afterwards (usually the 2 outer measurements). We then calculated means of the measurements taken during and after nursery habitat occupancy, and these means were used for data analyses.

Trace elements were measured using a VG Elemental PlasmaQuad 2+ ICP-MS coupled with a custom laser ablation system (based on a LUMONICS YM-200 Nd-YAG laser). In preparation for analysis, the cover slip and otolith was placed in a sealed quartz chamber on a microscope stage. The laser beam was focused at the surface of the otolith and the site of each sample 
was briefly pre-ablated to remove surface contaminants. The laser was run in Q-switched mode with a beam wavelength of $355 \mathrm{~nm}$. The laser was pulsed at $2 \mathrm{~Hz}$ to ablate a sample, and each pulse was approximately $5 \mathrm{~mJ}$. Each sample crater was 45 to $70 \mu \mathrm{m}$ in diameter. Ablated material was transported from the quartz chamber to the ICP-MS torch by an argon gas stream. Data were acquired in multi-element scan mode using 20 channels per atomic mass unit, a dwell time of $320 \mu$ s per channel (for a total of $0.5 \mathrm{~s}$ per sweep of the mass range), and an total acquisition time of $45 \mathrm{~s}$ per location.

Rigorous calibration approaches for LA-ICP-MS (Gunther et al. 2000) had not been developed when our analyses were done, and matrix-matched standards were not available. We did, however, ablate a glass standard (NBS 612) and use this to calculate elemental concentrations. The glass standard and samples are not matrix-matched, and so the accuracy of the calculated concentrations is poor (Perkins et al. 1991). They were, however, sufficient for our purpose, which was simply to assess in rough terms whether the laserablation and solution-based measurements were comparable. Specifically, we wished to ensure that any high concentrations recorded in the laser samples were not an artefact of contamination. We present data on 4 elements previously evaluated as natural tags in the juvenile otoliths ( $\mathrm{Mn}, \mathrm{Cu}, \mathrm{Sr}$, and $\mathrm{Pb})$. Six of the 95 samples were below detection limits (mean blank count rate $+3 \times \mathrm{SD}$ ) for $\mathrm{Pb}$, but all samples were above limits for the other 3 elements.

Our test for natural tags in larger halibut is not dependent on quantitatively accurate laser ablation data, and is based on the following qualitative predictions about trace element profiles in the otoliths of large halibut. Since offshore adult habitat and inshore open coast nursery sites have quite similar physiochemical properties, a large halibut that had occupied an open coast nursery should display no marked change in trace element composition from the center to edge of the otolith. A halibut originating from a bay nursery should, in contrast, show distinctly elevated levels of $\mathrm{Cu}$ and $\mathrm{Pb}$, but only in the central part of the otolith that was deposited in the nursery area. The outer region of the otolith should have lower levels of $\mathrm{Cu}$ and $\mathrm{Pb}$ comparable to fish originating on the open coast. Elements not elevated in bay juveniles (Mn and Sr) should not occur at high levels at the otolith center and should show little change in concentration from otolith center to edge.

We had previously tested discriminant models to classify juveniles of know origin as having come from bay or open coast habitat (the most accurate model was one using $\mathrm{Cu}$ and $\mathrm{Pb}$, see 'Results'). To test whether the elemental tag derived from analysis of juvenile otoliths yielded plausible predictions about prior use of nursery habitats by larger fish, we generated a discriminant model to classify the larger halibut to a nursery habitat. Since the solution-based and laser-based data were not comparable in strict quantitative terms, this new discriminant model was parameterized with normalized residuals (mean $=0, \mathrm{SD}=1$ ) of $\mathrm{Cu}$ and $\mathrm{Pb}$ concentrations from the juvenile halibut of known origin. Use of residuals assumes that the 2 sets of data come from the same underlying distribution. The new model was then used to classify the 19 larger halibut of unknown origin using the normalized residuals of $\mathrm{Cu}$ and $\mathrm{Pb}$ measured in the central part of the otolith.

\section{RESULTS}

\section{Differences in otolith chemistry of juvenile halibut occupying bay and open coast nurseries}

We first used a 1-factor ANOVA to compare nursery habitats just in 1998, the year when we collected halibut from both habitats. Two trace elements ( $\mathrm{Sr}$ and $\mathrm{Ba}$ ) showed no significant difference in concentration in juveniles from bay and open coast habitats ( $\mathrm{Sr}: F_{1,132}=$ $1.73, \mathrm{p}=0.190 ; \mathrm{Ba}: F_{1,132}=0.12, \mathrm{p}=0.726$; Fig. 3 ). The remaining 3 elements ( $\mathrm{Mn}, \mathrm{Cu}$ and $\mathrm{Pb}$ ) showed greater potential as markers of nursery habitat residence because they were at significantly higher concentrations in the otoliths of 1998 bay juveniles than in opencoast juveniles in the same year $\left(\mathrm{Mn}: F_{1,132}=19.2\right.$, $\mathrm{p}<0.0001 ; \mathrm{Cu}: F_{1,132}=28.2, \mathrm{p}<0.0001 ; \mathrm{Pb}: F_{1,132}=38.4$, $\mathrm{p}<0.0001$; Fig. 3).

We next used a 1-factor ANOVA followed by a Tukey's multiple comparison to test whether elemental concentrations of the 1998 open coast juveniles differed from bay juveniles collected during 1994, 1995, 1996 and 1997 as well as in 1998. A different subset of the 1998 bays was sampled in each of these other years, and we sampled 2 additional bays not sampled in 1998 (Table 1). This was not a rigorous test for temporal change in bays, but simply assessed whether bay juveniles remained different from open coast juveniles when additional years (and sites) were added to the comparison. These analyses confirmed that $\mathrm{Ba}$ and $\mathrm{Sr}$ were poor markers of nursery habitat because only in some years did bay juveniles differ from the 1998 open coast fish (Fig. 3). In addition, Mn was revealed as an unreliable indicator of nursery occupancy because, despite the clear difference between habitats detected in 1998, the collections of bay juveniles from 1994 to 1997 did not differ from the open coast juveniles (Fig. 3). The 2 most promising elements were $\mathrm{Cu}$ and $\mathrm{Pb}$ because these elements were at lower concentrations in the 1998 open coast juveniles than in any of the 

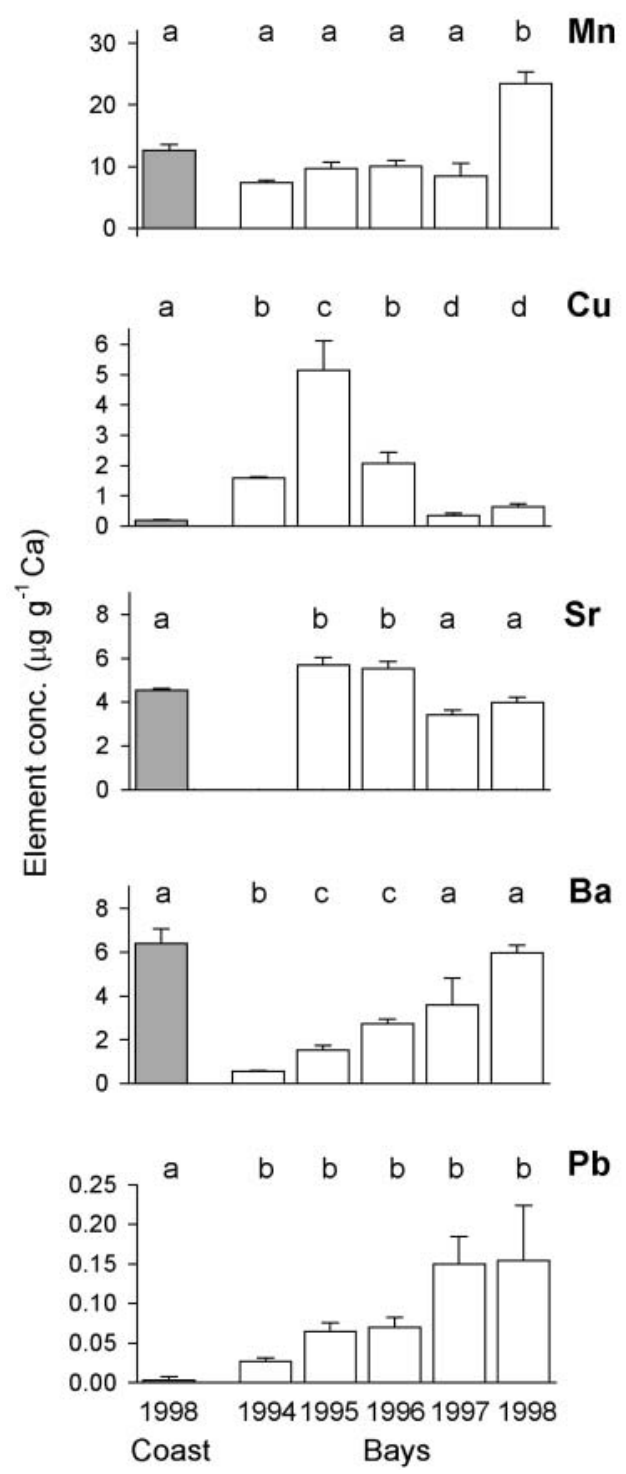

Fig. 3. Paralichthys californicus. Trace elements in the otoliths of juvenile halibut collected from open coast (gray bars) and bay (open bars) nursery sites. Plotted are means (with SE) for each year sampled in each habitat. Sample sizes and locations are given in 'Materials and methods' and in Table 2. Note that the number of bays sampled and sample sizes per bay differ among years. Letters above bars indicate results of a Tukey's test comparing means. Means not significantly different ( $p$ > 0.05 ) are indicated by the same letter

collections of bay juveniles (Fig. 3). Because of their greater promise as markers of habitat use, we concentrated our further analyses on $\mathrm{Cu}$ and $\mathrm{Pb}$.

Since we collected juveniles from the open coast in 1998 only, we could not test for interannual consistency in trace element concentrations within this habitat. The samples were, however, scattered widely over the study area (Fig. 1) and this, coupled with the low within-sample variation (Fig. 3), indicates that there was little spatial variation in $\mathrm{Cu}$ and $\mathrm{Pb}$ concentrations within the open coast nursery habitat. For bay juveniles, we were able to test for both spatial and interannual variation in otolith chemistry within this habitat. We used 1-factor ANOVAs to test for (1) differences among years in a single bay and (2) differences among bays in a given year (Table 1). We had large enough samples from 3 bays to meaningfully test for differences among years: Anaheim Bay (1994 and 1996), Carpinteria Marsh (1994, 1995 and 1996), and Los Alamitos Bay (1994 and 1996). For each of the 3 bays, there were differences among years in otolith $\mathrm{Cu}$ concentrations (Anaheim: $F_{1,26}=21.5, \mathrm{p}<0.0001$; Carpinteria: $F_{2,44}=8.82, \mathrm{p}=0.001$; Los Alamitos: $F_{1,41}=17.6$, $\mathrm{p}<0.0001)$. Otolith $\mathrm{Pb}$ concentrations were more temporally consistent, varying among years in Los Alamitos $\left(F_{1,41}=11.1, \mathrm{p}=0.002\right)$, but not in Carpinteria $\left(F_{2,44}=1.68,, \mathrm{p}=0.198\right)$ and Anaheim $\left(F_{1,26}=0.36\right.$, $\mathrm{p}=0.553)$. To test for differences among bays within a single year, we used data from 1994 and 1996 (the 2 years for which we had the largest samples). In 1994, juveniles collected from different individual bays varied significantly in otolith $\mathrm{Pb}$ concentrations $\left(F_{2,57}=\right.$ $3.21, \mathrm{p}=0.048$ ), but not in $\mathrm{Cu}$ concentrations (ANOVA, $\mathrm{p}=0.31$ ). In 1996, the pattern was reversed. There were significant among-bay differences in otolith $\mathrm{Cu}$ concentrations $\left(F_{3,55}=14.9, \mathrm{p}<0.0001\right)$ but not in levels of $\mathrm{Pb}\left(F_{3,55}=2.19, \mathrm{p}=0.099\right)$. Overall, open coast juveniles had low and spatially consistent levels of $\mathrm{Cu}$ and $\mathrm{Pb}$ in their otoliths. In contrast, otoliths of bay juveniles had higher and more variable levels of $\mathrm{Cu}$ and $\mathrm{Pb}$, which was due both to differences among individual bays and to change among years (Table 1).

When we pooled all samples, it was possible to assign the juveniles to their habitat of origin fairly accurately using trace element concentrations in their otoliths. A discriminant model using $\mathrm{Cu}$ alone correctly classified $76 \%$ of the bay juveniles and $86 \%$ of the open coast juveniles (78\% overall). A model using $\mathrm{Pb}$ alone also had high classification accuracy $(87 \%$ for bay juveniles, $68 \%$ for juveniles from the open coast and $83 \%$ overall). A model using data on both of these elements was similarly accurate $(84 \%$ accuracy for bay juveniles, $81 \%$ for juveniles from the open coast and $83 \%$ overall). Other discriminant models that included data on Mn, Sr and Ba did not increase the accuracy of classification over that attained using $\mathrm{Cu}$ and $\mathrm{Pb}$.

\section{Differences in sediment trace-element chemistry among nursery habitats}

A 2-factor ANOVA indicated that mean Mn concentrations $\left(\mu \mathrm{g} \mathrm{g}^{-1}\right)$ in sediments did not differ significantly between bay and open coast nursery habitats overall 
(coast mean $\pm \mathrm{SE}=404.1 \pm 13.4$, bay mean $\pm \mathrm{SE}=$ $\left.416.0 \pm 12.771, F_{1,546}=0.75, \mathrm{p}=0.387\right)$, and there was no interaction $\left(F_{8,546}=1.10, \mathrm{p}=0.210\right)$ that might indicate a difference between nursery habitats occurring in some, but not all years. Manganese concentrations did, however, differ significantly among years $\left(F_{8,546}=2.30, \mathrm{p}=0.020\right)$. To check that the results were not biased by pooling data from the 5 monitoring programs, we used 1-factor ANOVAs to compare the 2 nursery habitats using data from each monitoring program separately. In all cases, the 1-factor ANOVAs produced qualitatively similar results to those just described for analyses on pooled data (detailed results not presented). At a finer spatial scale, Mn concentrations in sediments and otoliths from the same individual bay were not correlated $(n=6, r=0.52$, $p=0.287$ ). Overall then, $\mathrm{Mn}$ in sediments showed a similar pattern to $\mathrm{Mn}$ in otoliths in that no consistent difference between bay and open coast habitats was observed.

In contrast, both $\mathrm{Cu}$ and $\mathrm{Pb}$ had significantly higher mean concentrations in bay sediments than in sediments at open coast nursery sites $\left(\mathrm{Cu}: F_{1,817}=42.9\right.$, $\mathrm{p}<0.0001 ; \mathrm{Pb}: F_{1,817}=30.6, \mathrm{p}<0.0001 ;$ Fig. 2$)$. The lack of a significant interaction in the ANOVA $\left(\mathrm{Cu}: F_{11,817}=\right.$ $1.67, \mathrm{p}=0.076 ; \mathrm{Pb}: F_{11,817}=1.01, \mathrm{p}=0.436$ ) shows that this difference was maintained across all 11 yr sampled (Fig. 2) and for neither $\mathrm{Cu}$ nor Pb did mean concentrations differ significantly among years $\left(\mathrm{Cu}: F_{11,817}=\right.$ $\left.1.51, \mathrm{p}=0.124 ; \mathrm{Pb}: F_{11,817}=1.37, \mathrm{p}=0.327\right)$. At this broad spatial scale then, $\mathrm{Cu}$ and $\mathrm{Pb}$ in otoliths and sediments showed a similar pattern in that both elements occurred at higher and more variable concentrations in bays than on the open coast. As was the case for Mn, analyses of the data for each monitoring program separately produced results that were qualitatively similar to those on the pooled data (detailed results not presented). At a finer spatial scale, when we compared samples originating from the same bay in the same year, the match between sediments and otoliths was poorer. Juvenile halibut had concentrations of $\mathrm{Cu}$ and $\mathrm{Pb}$ in their otoliths that were not significantly correlated with the concentration of those elements in the sediment of their home bay $(\mathrm{Cu}: \mathrm{n}=9, \mathrm{r}=0.66, \mathrm{p}=$ 0.054; $\mathrm{Pb}: \mathrm{n}=9, \mathrm{r}=0.38, \mathrm{p}=0.318$ ).

\section{Assessing the potential to define past nursery habitat use in older halibut}

Trace element profiles in the otoliths of the 19 larger halibut provide tentative support for the hypothesis that otoliths retain chemical tags indicating prior nursery habitat use. First, $\mathrm{Mn}, \mathrm{Cu}, \mathrm{Sr}$, and $\mathrm{Pb}$ concentrations estimated using the glass standard fell within the range of concentrations measured by solution-based analysis of juvenile otoliths (Fig. 4), suggesting that relative differences among laser samples are probably indicative of habitat use and not contamination or other artifacts.

The discriminant model parameterized using normalized residuals of $\mathrm{Cu}$ and $\mathrm{Pb}$ concentrations in juvenile otoliths classified 11 of the large halibut as being of bay origin and 8 as having occupied open coast

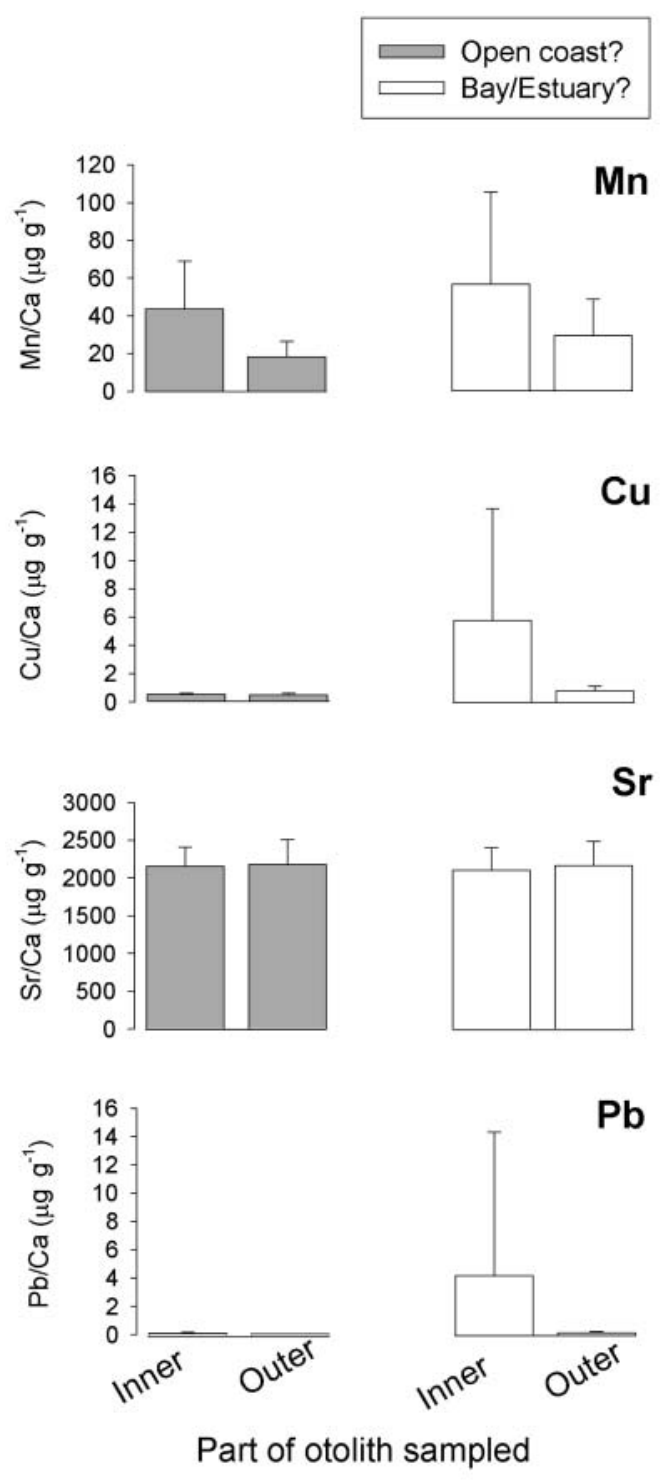

Fig. 4. Paralichthys californicus. Laser ablation ICP-MS analysis of trace elements in the otoliths of 19 large California halibut. Fish are grouped into those classified by a discriminant model as likely to have previously occupied open coast nurseries (left panel) and those that may have occupied bay nurseries (right panel). Each cross-sectioned otolith was sampled at 2 to 3 central locations deposited while a juvenile in a nursery habitat (during) and at 2 to 3 locations closer to the edge that were deposited after migration offshore to adult habitat (after). Plotted are mean concentrations (with SE) for each group 
nurseries. Trace element profiles of these otoliths are consistent with our expectations about relative differences between parts of the otolith deposited during and after nursery habitat occupancy, and so suggest that these assignments are plausible (Fig. 4). Otoliths of the 8 halibut classified as originating from open coast nurseries showed minor changes in the concentration of all 4 trace elements from the otolith center to outer edge, a profile consistent with having spent their first yr in an open coast nursery and then migrated offshore to the adult habitat (Fig. 4). The 11 halibut classified as having occupied bay nurseries contained elevated levels of $\mathrm{Cu}$ and $\mathrm{Pb}$, but only in the part of the otolith deposited in a nursery. The other elements, which were not significantly elevated in bay juveniles, showed little (Mn) or no (Sr) tendency to be elevated in the otolith centres of these 11 halibut. This trace element profile is thus suggestive of early residence in a bay nursery followed by movement to the offshore adult habitat (Fig. 4).

\section{DISCUSSION}

\section{Reliable natural tags in juvenile California halibut otoliths?}

The use of trace element concentrations in otoliths as a reliable natural tag requires firstly that otoliths of fish from the locations to be discriminated are chemically distinct. This criterion has been met in studies done in various habitats, including studies showing that juvenile fish collected from specific bays or estuaries have distinct trace element differences that can be used as natural tags (Milton et al. 1997, Thorrold et al. 1998a,b, 2001). A second important criterion for a reliable natural tag is that the marker be consistent over the time interval for which it is desired to characterize site usage. Some of the aforementioned estuarine studies were based on collections from a single year, and it is not known whether the site-specific differences in otolith chemistry would be consistent among years (Thorrold et al. 1998a,b, 2001). In fact, 1 study showed that differences among estuaries detected in 1 year were replaced by a new set of differences in fish collected 1 yr later (Milton et al. 1997). Our results for juvenile California halibut showed a similar lack of among-year consistency in trace element concentrations of otoliths at the level of individual bays. In our system, the lack of a consistent small-scale tag may be because most of the bays used as nursery sites by California halibut are quite small, and dynamic in their physiochemical features. Anthropogenic and terrigenous inputs of trace elements vary among bays depending on watershed features, and the hydrographic regime is characterized by long summertime periods of low freshwater input, and restricted exchange with the ocean, interspersed with severe winter storms that 'reset' conditions in the bays (Nordby \& Zedler 1991). It thus remains possible that there may be more reliable elemental tags for individual bays or estuaries in regions where bays and estuaries are larger and more hydrologically stable.

Despite the variability among individual bays, our results suggest that some trace elements may be reliable markers of nursery habitat use for California halibut at a broader spatial scale (all bays vs all open coast sites). A similar broad-scale difference was identified by Gillanders \& Kingsford $(1996,2000)$, who were able to differentiate between the use of estuarine seagrass habitats and coastal reefs by juveniles of 2 species. These workers sampled juveniles in 1 year only. Two features of our results suggest that the difference between bay and open coast habitats in southern California is likely to be maintained over several years. Firstly, the difference between the 2 habitats that we detected in 1998 persisted when the bay sample was expanded to include additional sites and samples spanning 4 yr. Secondly, $\mathrm{Cu}$ and $\mathrm{Pb}$ in sediments were consistently lower in concentration on the open coast than in bays over 12 yr. If habitat-specific differences in otoliths and sediments are linked, this implies a temporally stable natural tag in juvenile halibut otoliths. Of course, establishing a causal link between elements in otoliths and sediments, or data on the otoliths of open coast juveniles over several years would be required to confirm that the natural tag shows long-term stability.

\section{What causes habitat-specific differences in otolith trace element composition?}

When we compared all bay samples to all open coast samples, $\mathrm{Cu}$ and $\mathrm{Pb}$ showed similar patterns of relative difference among habitats in otoliths and sediments. The fact that mean concentrations in the 2 habitats differed by similar amounts, and that variation around the means was of similar magnitude (compare Figs. 2 \& 3), suggests some association between levels of $\mathrm{Cu}$ and $\mathrm{Pb}$ in otoliths and sediments. The fact that $\mathrm{Cu}$ and $\mathrm{Pb}$ concentrations in halibut otoliths did not match the subtler differences among sediments at a finer spatial scale (individual bays) indicates, however, that the association is not a tight one (see also Hanson \& Zdanowicz 1999).

Our limited understanding of mechanisms regulating trace element deposition in otoliths makes it difficult to isolate the causal process underlying the correlation between $\mathrm{Cu}$ and $\mathrm{Pb}$ in sediments and otoliths. Two likely underlying causes are the uptake of dissolved $\mathrm{Cu}$ and $\mathrm{Pb}$ from the water column and/or 
uptake across the gut of $\mathrm{Cu}$ and $\mathrm{Pb}$ from the tissues of ingested prey (Campana 1999). Both of these forms of $\mathrm{Cu}$ and $\mathrm{Pb}$ display a qualitatively similar concentration gradient to that observed in sediments: high levels in bays and lower levels on the open coast (Chapman et al. 1987, Johnson et al. 1988, Flegal \& SañudoWilhelmy 1993, van Geen \& Luoma 1993, SañudoWilhelmy \& Flegal 1996, Fairey et al. 1998, Zirino et al. 1998). Laboratory experiments indicate that $\mathrm{Cu}$ and $\mathrm{Pb}$ are deposited in otoliths in proportion to their dissolved concentration in the surrounding water (Milton \& Chenery 2001), as are Sr and Ba (Farrell \& Campana 1996, Bath et al. 2000). As yet, however, there is no direct experimental evidence indicating that $\mathrm{Cu}$ and $\mathrm{Pb}$ deposition is a function of their concentration in the tissues of prey (Milton \& Chenery 2001).

\section{Applications of natural tags in California halibut}

Our laser-ablation analysis of larger halibut suggests that the elemental tag of the 2 nursery habitats may be identifiable in older fishes. The classification algorithm we developed using the data on juveniles (of known origin) yielded a plausible prediction of prior nursery use by sub-adults (of unknown origin). We were forced to use residuals of elemental concentrations in this classification algorithm because the ICP-MS protocols used on adults and juveniles yielded raw data that were not quantitatively equivalent. This procedure is robust, as long as the 2 sets of raw data have similar underlying distributions; in other words, as long as the 2 methods are free of artifacts (see also Thorrold et al. 2001). A better approach would be to use the same ICP-MS protocol to analyse both juvenile otoliths and the core of adult otoliths (e.g. Gillanders \& Kingsford 1996) so that a classification algorithm for juveniles (of known origin) could be used directly to predict prior nursery occupancy of adults (of unknown origin). By analysing a large representative sample of adults it may thus be possible to estimate the fraction of individuals recruiting to the adult population that originated from bay nurseries.

Such an estimate could prove useful in management of the California halibut population, which has declined steadily over the past 30 yr (Plummer et al. 1983, Kramer \& Sunada 1992). One of the possible causes of this decline is the loss of bay nursery habitat (California Coastal Zones Commission 1975). If collections of otoliths made in the past were available, it might even be possible to assess whether the fraction of recruits coming from bay nurseries has declined over time and so test the habitat-loss hypothesis directly. The loss and deterioration of coastal wetlands and bays is a widespread phenomenon, and the use of trace ele- ments as natural tags to quantify the supply of recruits to fisheries from specific inshore habitats may be a useful technique for assessing 1 aspect of the functional status of those sites - as fish nurseries.

Acknowledgements. Many thanks to Linda O'Bryan, Julie Standish and Chau Tran for help with lab work and analyses. We also appreciate the assistance of Andy Brooks, Tina Hartney, and the many participants in the 'Bight 98' monitoring program who donated halibut and/or allowed us to participate in their collecting trips. Thanks to the following organizations for providing access to their chemical monitoring data: Bay Protection and Toxic Cleanup Program, Los Angeles County Sanitation District, NOAA National Status and Trends Program, Southern California Coastal Water Research Project, California State Mussel Watch. We are very grateful to Rob Franks for advice on ICP-MS and hospitality during visits to the Marine Analytical labs at UC Santa Cruz to use the Finnegan Element, to David Lea for advice and use of his VG Elemental Plasmaquad and lab facilities at UC Santa Barbara, and to Dr. Sam Wang at Elemental Research, who ran the LA-ICP-MS. The manuscript benefited from comments by the reviewers and Lisa Levin. Both authors were partially supported by traineeships from the UC Coastal Toxicology Program. Further financial support was provided by a grant to S.S. from the Conservation and Research Foundation and a grant to G.E.F. from the NOAA National Sea Grant College Program, through the California Sea Grant College System (project R/F-171), and the California State Resources Agency. The views expressed herein are those of the authors and do not necessarily reflect the views of NOAA or any of its sub-agencies. The US Government is authorized to reproduce and distribute for governmental purposes.

\section{LITERATURE CITED}

Able KW, Fahay MP (1998) The first year in the life of estuarine fishes in the Middle Atlantic Bight. Rutgers University Press, New Brunswick, NJ

Allen LG, Herbinson KT (1990) Settlement of juvenile California halibut, Paralichthys californicus, along the coasts of Los Angeles, Orange, and San Diego counties in 1989. Calif Coop Ocean Fish Invest Rep 31:84-96

Allen LG, Fensen RE, Sears JR (1990) Open coast settlement and distribution of young-of-the-year California halibut, Paralichthys californicus, along the southern California coast between Point Conception and San Mateo Point, June-October, 1988. Fish Bull 174:145-152

Bath GE, Thorrold SR, Jones CM, Campana SE, McLaren JW, Lam JWH (2000) Strontium and barium uptake in aragonitic otoliths of marine fish. Geochim Cosmochim Acta 64: 1705-1714

California Coastal Zone Conservation Commissions (1975) California coastal plan. State Printing Office, Sacramento, CA

Campana SE (1999) Chemistry and composition of fish otoliths: pathways, mechanisms and applications. Mar Ecol Prog Ser 188:263-297

Campana SE, Gagne A (1994) Cod stock discrimiation using ICP-MS elemental assays of otoliths. In: Secor DH, Dean JM, Campana SE (ed) Recent developments in otolith fish research. University of South Carolina Press, Columbia, p 671-691

Campana SE, Fowler AJ, Jones CM (1994) Otolith elemental fingerprinting for stock identification of Atlantic cod (Gadus morhua) using laser ablation ICP-MS. Can J Fish Aquat Sci 51:1942-1950 
Campana SE, Gagne A, McLaren JW (1995) Elemental fingerprinting of fish otoliths using ID-ICP-MS. Mar Ecol Prog Ser 122:115-20

Campana SE, Chouinard GA, Hanson JM, Frechet A (1999) Mixing and migration of overwintering atlantic cod (Gadus morhua) stocks near the mouth of the Gulf of St. Lawrence. Can J Fish Aquat Sci 56:1873-1881

Chapman PM, Dexter RN, Long ER (1987) Synoptic measures of sediment contamination, toxicity and infaunal composition (the sediment quality triad) in San Francisco Bay. Mar Ecol Prog Ser 37:75-96

City of Los Angeles (1997) Marine monitoring in Santa Monica Bay: biennial assessment report for January 1995 through December 1996. Environmental Monitoring Division Bureau of Sanitation, City of Los Angeles

Cyrus DP, Martin TJ (1991) The importance of estuaries in life histories of flatfish species on the southern coast of Africa. Neth J Sea Res 27:255-260

Edmunds JS, Caputi N, Morita M (1991) Stock discrimination by trace-element analysis of otoliths of orange roughy (Hoplostethus atlanticus), a deep-water marine teleost. Aust J Mar Freshw Res 42:383-389

Fairey R, Roberts C, Jacobi M, Lamerdin S and 9 others (1998) Assessment of sediment toxicity and chemical concentrations in the San Diego Bay region, California, USA. Environ Toxicol Chem 17:1570-1581

Farrell J, Campana SE (1996) Regulation of calcium and strontium deposition on the otoliths of juvenile tilapia, Oreochromis niloticus. Comp Biochem Phys A 115:103-109

Ferren WR, Fiedler PL, Leidy RA (1996) Wetlands of the central and southern California coast and coastal watersheds: a methodology for their classification and description. Final Report, United States Environmental Protection Agency, San Francisco

Flegal AR, Sañudo-Wilhelmy SA (1993) Comparable levels of trace metal contamination in two semi-enclosed embayments: San Diego Bay and South San Francisco Bay. Environ Sci Technol 27:1934-1936

Fowler AJ, Campana SE, Jones CM, Thorrold SR (1995a) Experimental assessment of the effect of temperature and salinity on elemental composition of otoliths using solution-based ICP-MS. Can J Fish Aquat Sci 52:1421-30

Fowler AJ, Campana SE, Jones CM, Thorrold SR (1995b) Experimental assessment of the effect of temperature and salinity on elemental composition of otoliths using laser ablation ICP-MS. Can J Fish Aquat Sci 52:1431-41

Frey HW (1971) California's living marine resources and their utilization. Calif Fish Game, Sacramento

Geffen AJ, Pearce NJG, Perkins WT (1998) Metal concentrations in fish otoliths in relation to body composition after laboratory exposure to mercury and lead. Mar Ecol Prog Ser 165:235-245

Gillanders BM, Kingsford MJ (1996) Elements in otoliths may elucidate the contribution of estuarine recruitment to sustaining coastal reef populations of a temperate reef fish. Mar Ecol Prog Ser 141:13-20

Gillanders BM, Kingsford MJ (2000) Elemental fingerprints of otoliths of fish may distinguish estuarine nursery habitats. Mar Ecol Prog Ser 201:73-86

Gunther D, Horn I, Hattendorf B (2000) Recent trends and developments in laser ablation-ICP-mass spectrometry. Fresenius J Analyt Chem 368:4-14

Haaker PL (1975) The biology of the California halibut, Paralichthyes californicus (Ayres) in Anaheim Bay, California. In: Lane ED, Hill CW (eds) The marine resources of Anaheim Bay. Calif Dept of Fish and Game Fish Bull 165: $137-153$
Hanson PJ, Zdanowicz VS (1999) Elemental composition of otoliths from Atlantic croaker along an estuarine pollution gradient. J Fish Biol 54:656-668

Houde ED, Rutherford ES (1993) Recent trends in estuarine fisheries: predictions of fish production and yield. Estuaries 16:161-176

Jensen RE (1990) The aging, validation, and back-calculation of the date of birth and settlement date of young-of-theyear California halibut (Paralichthys californicus) into Alamitos Bay, California using a new technique for the grinding of sagittal otoliths. MS thesis, California State University, Northridge

Johnson KS, Stout PM, Berelson WM, Sakamoto-Arnold CM (1988) Cobalt and copper distributions in the waters of Santa Monica Basin, California. Nature 332:527-530

Johnson RA, Wichern DW (1998) Applied multivariate statistical analysis, 4th edn. Prentice Hall, Englewood Cliffs, NJ

Kerstan M (1991) The importance of rivers as nursery grounds for 0- and 1-group flounder (Platichthys flesus L.) in comparison to the Wadden Sea. Neth J Sea Res 27:353-366

Kramer SH (1990) Distribution and abundance of juvenile California halibut, Paralichthys californicus, in shallow waters of San Diego County. Fish Bull 174:99-126

Kramer SH (1991) Growth, mortality, and movements of juvenile California halibut Paralichthys californicus in shallow coastal and bay habitats of San Diego County, California. Fish Bull 89:195-207

Kramer SH, Sunada JS (1992) California halibut. In: Leet W, Dewees CM, Haugen CW (eds) California's living marine resources and their utilization. UC Sea Grant Program, San Diego, p 94-97

Lackenbruck PA, Mickey MR (1968) Estimation of error rates in discriminant analysis. Technometrics 10:1-11

Lauenstein GG, Cantillo AY (1993) Sampling and analytical methods of the NS\&T Program National Benthic Surveillance and Mussel Watch Projects. Comprehensive descriptions of elemental analytical methods. NOAA Tech Memo 71. NOAA/NOS/ORCA, N/ORCA 21, Silver Spring, MD

Mearns AJ, Matta MB, Shigenaka G, MacDonald D, Buchman M, Harris H, Golas G, Lauenstein G (1991) Contaminant trends in the Southern California Bight: inventory and assessment. NOAA Tech Memo NOS OMA 62, Seattle, WA

Milton DA, Chenery SR (1998) The effect of otolith storage methods on the concentrations of elements detected by laser-ablation ICP-MS. J Fish Biol 53:785-794

Milton DA, Chenery SR (2001) Sources and uptake of trace metals in otoliths of juvenile barramundi (Lates calcarifer). J Exp Mar Biol Ecol 264:47-65

Milton DA, Chenery SR, Farmer MJ, Blaber SJM (1997) Identifying the spawning estuaries of the tropical shad, Terubok tenualosa Toli, using otolith microchemistry. Mar Ecol Prog Ser 153:1-13

Moser HG, Watson W (1990) Distribution and abundance of early life history stages of the California halibut, Paralichthys californicus, and comparison with the fantail sole, Xystreurys liolepis. SW Fisheries Center Admin Rep LJ-90-04, San Diego

Mugiya Y, Hakomori T, Hatsutori K (1991) Trace metal incorporation into otoliths and scales in the goldfish, Carassuis auratus. Comp Biochem Physiol 99C:327-331

Nordby CS, Zedler JB (1991) Responses of fish and macrobenthic assemblages to hydrologic disturbances in Tijuana Estuary and Los Penasquitos Lagoon, California (USA). Estuaries 14:80-93

Patterson HM, Thorrold SR, Shenker JM (1999) Analysis of otolith chemistry in Nassau grouper (Epinephelus striatus) 
from the Bahamas and Belize using solution-based ICPMS. Coral Reefs 18:171-178

Perkins WT, Fuge R, Pearce NJG (1991) Quantitative analysis of trace elements in carbonates using laser ablation inductively coupled plasma mass spectrometry. J Analy Atomic Spectr 6:445-449.

Plummer KM, DeMartini EE, Roberts DA (1983) The feeding habits and distribution of juvenile-small adult California halibut (Paralichthys californicus) in coastal waters off northern San Diego County. CalCOFI Rep 24:194-201

Rasmussen D (1996) State mussel watch program 1993-1995 data report. SWRCB, CA Env Protection Agency, Sacramento

Reichert MJM, van der Veer HW (1991) Settlement, abundance, growth and mortality of juvenile flatfish in a subtropical tidal estuary (Georgia, USA). Neth J Sea Res 27:375-391

Sañudo-Wilhelmy SA, Flegal AR (1996) Trace metal concentrations in the surf zone and in coastal waters off Baja California, Mexico. Environ Sci Technol 30:1575-1580

Schiff KC, Gossett R (1998) Southern California Bight 1994 Pilot Project: III. Sediment Chemistry. SCCWRP, Westminster

Stephenson M, Puckett M, Morgan N, Reid M (1994) Bay Protection and Toxic Cleanup Program Quality Assurance Project Plan. CA State Water Resources Control Board, Sacramento

Swearer SE, Caselle JE, Lea DW, Warner RR (1999) Larval retention and recruitment in an island population of a coral-reef fish. Nature 402:799-802

Editorial responsibility: Lisa Levin (Contributing Editor), La Jolla, California, USA
Szedlmayer ST, Able KW (1993) Ultrasonic telemetry of age-0 summer flounder, Paralichthys dentatus, movements in a southern New Jersey estuary. Copeia 3:728-736

Thorrold SR, Jones CM, Campana SE (1997) Response to otolith microchemistry to environmental variations experienced by larval and juvenile Atlantic croaker Micropogonias undulatus. Limnol Oceanogr 42:102-111

Thorrold SR, Jones CM, Campana SE, McLaren JW, Lam JWH (1998a) Trace element signatures in otoliths record natal river of juvenile american shad (Alosa sapidissima). Limnol Oceanogr 43:1826-1835

Thorrold SR, Jones CM, Swart PK, Targett TE (1998b) Accurate classification of juvenile weakfish Cynoscion regalis to estuarine nursery areas based on chemical signatures in otoliths. Mar Ecol Prog Ser 173:253-265

Thorrold SR, Latkoczy C, Swart PK, Jones CM (2001) Natal homing in a marine fish metapopulation. Science 291: 297-299

Valle CF, O'Brien JW, Wiese KB (1999) Differential habitat use by California halibut, Paralichthys californicus, barred sand bass, Paralabrax nebulifer, and other juvenile fishes in Alamitos Bay, California. Fish Bull 97:646-660

van Geen A, Luoma SN (1993) Trace metals (Cd, Cu, Ni, Zn) and nutrients in coastal waters adjacent to San Francisco Bay, California. Estuaries 16:559-566

Zirino A, Belli SL, van der Weele DA (1998) Copper concentration and $\mathrm{Cu}^{\mathrm{ii}}$ activity in San Diego Bay. Electroanalysis 10:423-427

Submitted: July 16, 2001; Accepted: March 7, 2002

Proofs received from author(s): September 3, 2002 